\title{
STATIC BEHAVIOR OF RC COLUMN JOINTS AS AFFECTED BY CHANGING OF ITS GRADE OF CONCRETE AND DETAILS OF REINFORCEMENT
}

\author{
Abdel Rahman Megahid Ahmed and Khairy Hassan Abdelkareem \\ Civil Engineering Department, Faculty of Engineering, Assiut University, Assiut, \\ Egypt
}

(Received June 3, 2006 Accepted June 22, 2006)

The columns of high-rise structures are usually constructed from high strength concrete and the connecting beams and slabs at floors are of normal strength concrete. Consequently, the beam column joint is of normal strength concrete. The purpose of the study is to investigate the strength of high strength concrete columns as affected by the low strength concrete of connecting beams, and to study the effect of reinforcement details of the joint of high strength concrete column and normal strength beam on failure mode of such column and its strength.

Experimental study was carried out to investigate the effect of changing the grade of concrete on the behavior of RC column and its joint considering the interaction of the column with the floor beams. Floor beams and the joint are constructed from normal strength concrete, while the other parts of the column below and above the joint are constructed using different grades of high strength and normal strength concretes. Another significant parameter affecting the behavior of such columns is the details of reinforcement of the joint represented by horizontal or inclined stirrups. Twelve specimens of $R C$ columns and intersecting beams are prepared and tested under axial compressive loading on the column as well as under vertical load on the beam. The results include the failure mode, strain distribution, ultimate load and strength of the columns considering the change of concrete strength and the details of reinforcement. It has been found that failure mode of such structures occurs at the joint because of its low strength which has been constructed with the floor beams. It has been shown that inclined stirrups at joints do not change the failure mode even it reduces its severity. Other steel arrangement is still needed to change the failure mode. However, inclined stirrups have significant influence on increasing the ultimate strength of the columns. This is because the inclined stirrups cause an increase on the shear strength of the column resulting in the increase of the strength. The strain distribution is highly affected by the interaction of beam and the column. Maximum strain occurred at the joint due to combined state of stress. An equation was deduced to estimate the strength of axially loaded columns considering the interaction of floor beams, variation of concrete strength and details of reinforcement. The deduced equation is applicable to normal strength and high strength concrete.

KEYWORDS: High Strength and Normal Strength Concrete, Column joint, inclined stirrups, failure mode, ultimate load, strength of column. 


\section{INTRODUCTION}

There is a rapid growth of interest in high strength concrete with compressive strength $\mathrm{fc}$ in the range of $55 \mathrm{MPa}(8000 \mathrm{psi})$ to $125 \mathrm{MPa}(1800 \mathrm{psi})$. These values are twice to four times the normal strength. The practical applications of high strength concrete have proceeded full knowledge of high strength concrete material properties and the behavior of structural members constructed with the material. One of the big advantages of high strength concrete is its use in columns of tall structures. For a given load, the high strength concrete column has a smaller cross sectional area and thus providing more floor space. Recent studies illustrated some properties of the higher strength concrete such as its high modulus of elasticity, less ductile mode of failure, and larger strain at maximum stress $[1-4]$. In the design of ductile moment resisting frames, it is desired to prevent the formation of flexural hinges in the columns. The beam column connection must resist forces without a significant loss of strength or stiffness. The joints should be designed for both ductility and strength. When using high strength concrete, the problem of ductility is of particular interest because of the brittle nature of plain high strength concrete [4].

Previous work $[5,6]$ demonstrated that the column strength was not limited to the strength of intervening floor slab but that, on the hand, the differential between the two concretes could not be too large. ACI code $[5,7]$ permits the column concrete to be as much as 1.4 times the slab concrete strength before other measures must be taken. For interior columns, where the joint region concrete in the slab between the ends of the column is confined by continuing slab concrete on all four sides, a partial remedy is suggested. So, the variables are variety of slab concrete compressive strength, the slab represent either interior or edge conditions and two different slab thickness are included. From the results, it is concluded that apparent strength relationships based on the ratio of column compressive strength to slab compressive strength $f_{\mathrm{cc}}^{\prime} / f^{\prime} \mathrm{cs}$ appear to be general across the full range of concrete strengths considered.

There are several studies to improve the ductility of high performance concrete for structural applications $[5,6,8,9,10]$. One economical solution to increase ductility of high strength concrete is through the optimization of the constituent properties. This requires fundamental understanding of the influence of the constituent materials and their interaction on global behavior of the material and structure. Another method to improve ductility is the proper details of reinforcement at joints. The use of spiral reinforcement results in increased strength and ductility of confined concrete. Concrete confined by rectangular ties exhibits less increase in strength and ductility. The increase of ductility and strength due to confinement is a subject of disagreement due to the less well-defined mechanism of rectilinear confinement and the variety of configurations of longitudinal bars and rectangular ties [9-12]. While the rectilinear confinement in square sections is not as effective as the spiral confinement, the square sections exhibit higher moment capacity than those of circular sections especially at large deformations. In an experimental study [6], it has been found that the use of HSC column increased connection shear strength compared to normal strength concrete by about $5 \%$ when the column is subject to normal force only, and by $17 \%$ when the column is subject to moment and axial force. They analyzed the behavior and shear 
strength of slab-connections constructed with combinations of HSC columns and normal strength concrete slabs. There are many studies concerning the behavior of high strength connections under static and seismic loading [13 - 17]

\section{PURPOSE OF STUDY}

The columns of high-rise structures are usually constructed from high strength concrete and the connecting beams and slabs at floors are of normal strength concrete. Consequently, the beam column joint is of normal strength concrete. This will affect the axial strength of columns and the behavior of the joint as well as the failure mode. It is necessary to define which strength is used to calculate the axial strength of column; the high strength of the column or the normal strength of the joint. This point is not studied clearly in previous studies. The purposes of the current study are summarized as follows: to investigate the strength of high strength concrete columns as affected by the low strength concrete of connecting beams, and to study the effect of details reinforcement of the joint of high strength concrete column and ordinary strength beam on failure mode and strength of the column.

\section{MATERIALS}

A- Concrete. Four grades of concrete are used as follows:

1- Normal strength concrete. Concrete mix design was carried out to produce normal strength concrete. The proportions are illustrated in Table 1. Ordinary Portland cement was used (Assiut Cement). A total of 39 standard cubes was casted and tested after 28 days. The average concrete strength of standard cubes $(15 \times 15 \times 15 \mathrm{~cm})$ is $250 \mathrm{kgf} / \mathrm{cm}^{2}$.

2- High strength concrete (HSC). Three grades of high strength concrete (HSC) were produced in the study. The concrete mix proportions by weight are given in Table 2.

Table 1: Concrete Mix proportions to produce Normal Strength Concrete.

\begin{tabular}{|c|c|c|c|}
\hline Cement kg/m $\mathrm{m}^{3}$ & Sand kg/m $\mathrm{m}^{3}$ & Gravel kg/m & water Litre $/ \mathrm{m}^{3}$ \\
\hline 350 & 670 & 1200 & $165(\mathrm{w} / \mathrm{c}=0.47)$ \\
\hline
\end{tabular}

Table 2: Concrete Mix proportions to produce High Strength Concrete.

\begin{tabular}{|l|c|c|c|c|c|c|c|}
\hline $\begin{array}{c}\text { Con. } \\
\text { grade }\end{array}$ & $\begin{array}{c}\text { cement } \\
\mathrm{kg} / \mathrm{m}^{3}\end{array}$ & $\begin{array}{c}\text { sand } \\
\mathrm{kg} / \mathrm{m}^{3}\end{array}$ & $\begin{array}{c}\text { Basalt } \\
\prec 10 \mathrm{~mm} \\
\mathrm{~kg} / \mathrm{m}^{3}\end{array}$ & $\begin{array}{c}\text { Basalt } \\
10-20 \mathrm{~mm} \\
\mathrm{~kg} / \mathrm{m}^{3}\end{array}$ & $\begin{array}{c}\text { Silica } \\
\text { fume } \\
\mathrm{kg} / \mathrm{m}^{3}\end{array}$ & $\begin{array}{c}\text { Sika- } \\
\text { mentFF-3 } \\
\mathrm{kg} / \mathrm{m}^{3}\end{array}$ & $\begin{array}{c}\text { water } \\
\text { Litre } / \mathrm{m}^{3}\end{array}$ \\
\hline C 900 & 550 & 450 & 600 & 600 & 110 & 20 & $140(\mathrm{w} / \mathrm{c}=0.26)$ \\
\hline C 700 & 500 & 525 & 600 & 600 & 90 & 17 & $125(\mathrm{w} / \mathrm{c}=0.25)$ \\
\hline C 500 & 450 & 600 & 600 & 600 & 70 & 14 & $165(\mathrm{w} / \mathrm{c}=0.37)$ \\
\hline
\end{tabular}

B. Steel Reinforcement: The longitudinal steel bars of column and the lower reinforcement of beam are of high strength ribbed bars of grade 36/52. The upper reinforcement of beam and the stirrups of both column and beams are of mild steel of grade 24/35. Diameters of the different steel bars are shown in Fig. 1. 


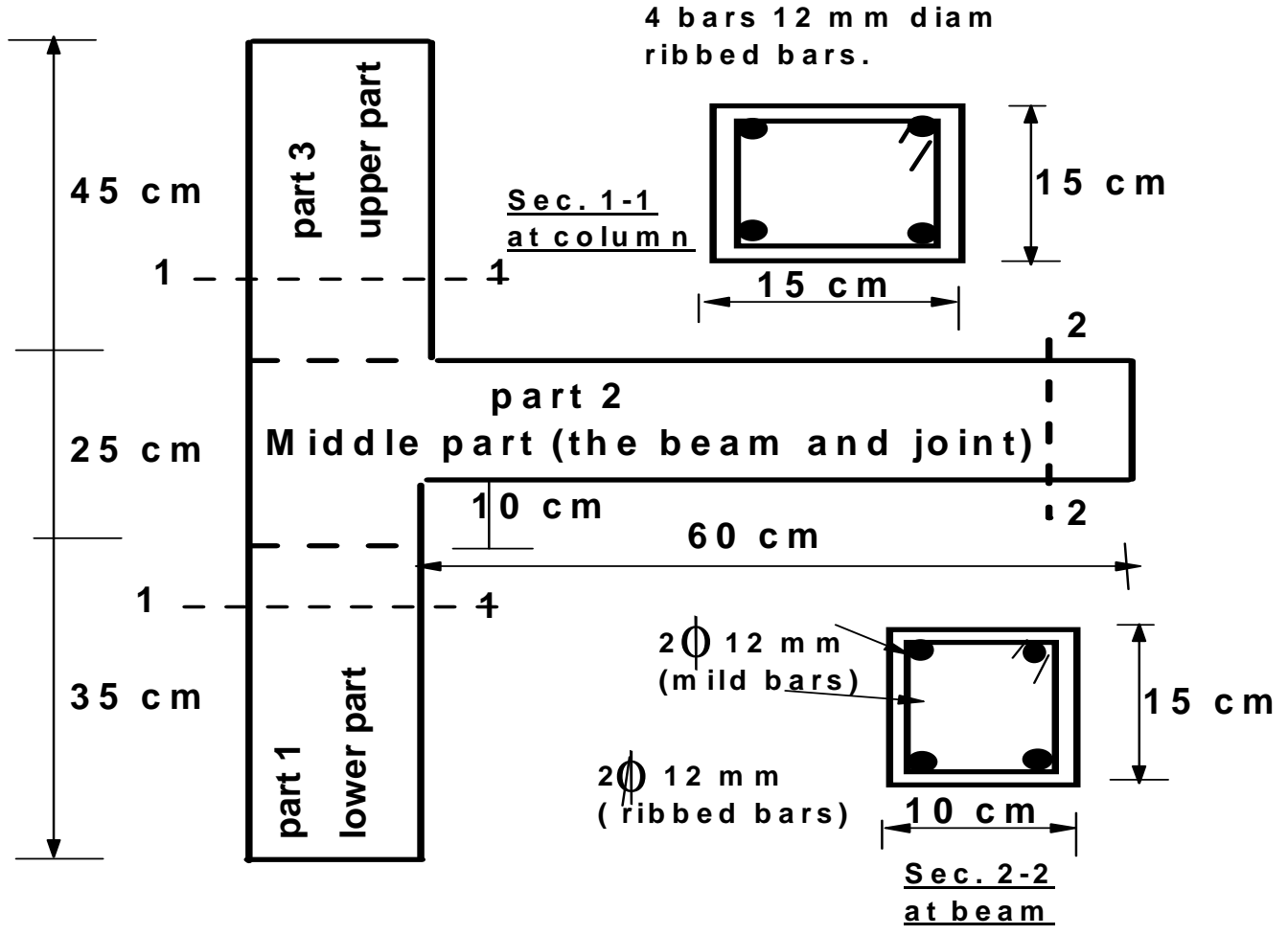

a) Details and dimensions of test specimens

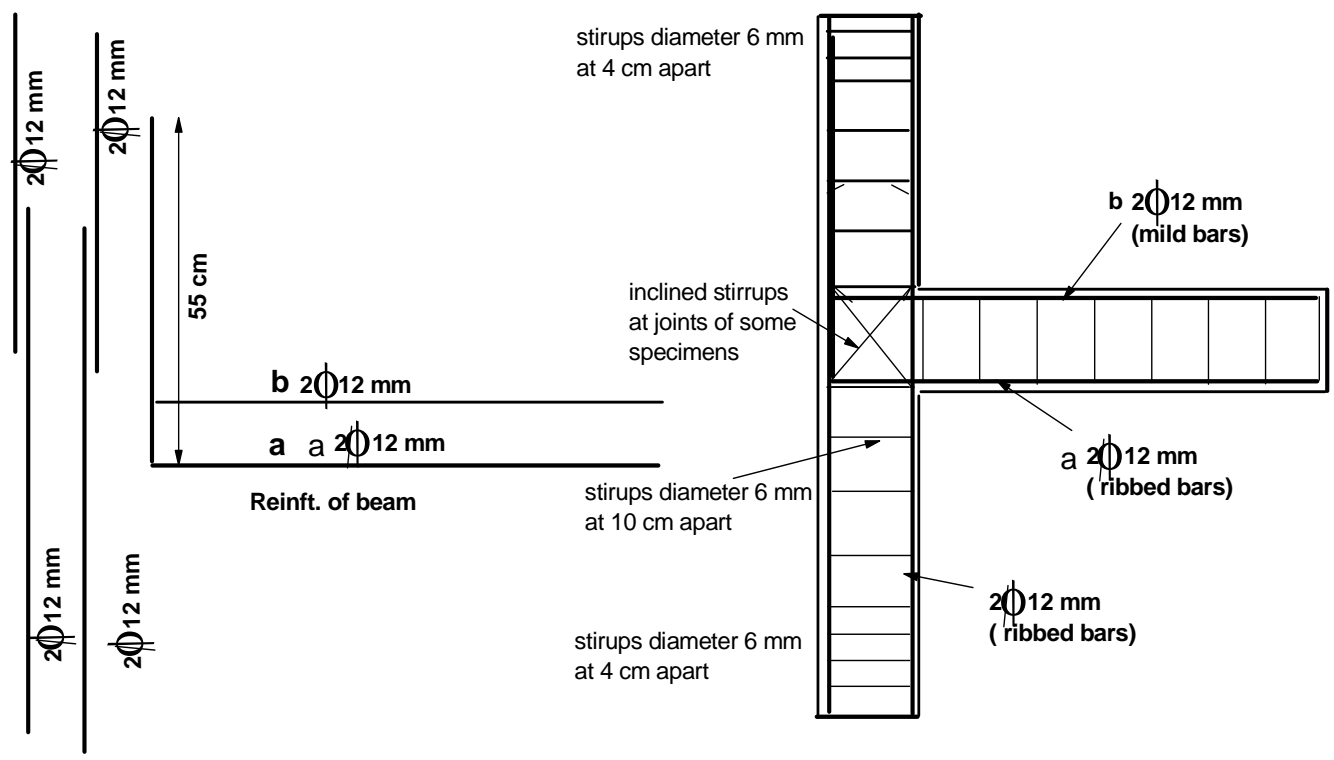

Reinft. of column

b) Details of reinforcement of specimens

Fig. 1 (a and $\mathbf{b}$ ): Test Specimens. 


\section{EXPERIMENTAL PROGRAM}

To reduce the area occupied by the columns, HSC is used to construct the columns especially in high-rise buildings. However, it is not practical to use HSC in floor beams and slabs because the beams and slabs should possess high ductility level rather than strength. Also, in the design of such structures, the theory of strong column - weak beam should be followed to assure the occurrence of plastic hinges in beams not in the columns. For such reasons, the floor beams and slabs are usually constructed using normal strength concrete. Also, the floor beams and slabs are casted monolithically with joint and a small part of column height below the beams. So, $10 \mathrm{~cm}$ height below the beam is casted at the same time with normal strength concrete. As it was mentioned, the purposes of this study are to investigate the strength of high strength concrete columns as affected by the low strength concrete of connecting beams, and to study the effect of details reinforcement of the joint of high strength concrete column and ordinary strength beam on failure mode of the column and its strength. In the current study, we will focus on the analysis of such phenomenon for exterior columns only. Another study for interior columns will be done.

To achieve the purposes, fourteen specimens were prepared and constructed at the Laboratory of reinforced concrete and strength of materials at Civil Department of Assiut University. Each specimen consists of three parts. The lower part of the column (part 1) has height of $35 \mathrm{~cm}$, the middle part (part 2) includes $25 \mathrm{~cm}$ of the column and joint and the beam, and the higher part of the column (part 3) has height of $45 \mathrm{~cm}$. This is done to be similar to the practical application, in which the column of the lower floor is casted, followed by the floor beams and slabs in the second stage, then the column of the higher floor. For this reason, the reinforcement of the column parts are spliced as shown in Fig. 1 in which the details, dimensions and reinforcement of the specimens are given. Table 3 summarizes the purpose of each specimen. Main reinforcement of column is 4 bars of diameter $12 \mathrm{~mm}$ of high tensile steel (\% of reinforcement is $2.0 \%$ ).

\section{SYSTEM OF LOADING}

All the specimens were tested after 28 days from the casting day. A testing machine of 500 tons capacity was utilized in testing the specimens. The movable head of the machine is the lower one. The loading system consists of two loads applied as follows:

1- A load was applied at $32.5 \mathrm{~cm}$ apart from the column face $(40 \mathrm{~cm}$ from the center line of the column) on the lower face of the beam. This load is applied from a special Jack. The load is applied at beginning of loading till the occurrence of cracking of the beam, then it was kept constant while applying the load on the column from the machine.

2- Compression load was applied on the column from the testing machine up to failure.

Figure 2 (a and $\mathbf{b}$ ) illustrates the loading system and the test setup. Figure $\mathbf{3}$ illustrates the boundary conditions and the straining actions on the system due to the given loading. The obtained results are represented by the cracking load of the beam, the ultimate load of the column, failure mode and strains at certain positions in the columns and the joint. 
Table 3: Details and Purpose of Tested Specimens.

\begin{tabular}{|c|c|c|c|}
\hline $\begin{array}{l}\text { specimen } \\
\text { No. }\end{array}$ & Description & Remarks & Purpose \\
\hline B-1 & Normal strength concrete & ---- & \multirow{2}{*}{$\begin{array}{l}\text { To test the loading set } \\
\text { up. No results were } \\
\text { obtained. }\end{array}$} \\
\hline B-2 & Normal strength concrete & --- & \\
\hline A-1 & $\begin{array}{l}\text { All parts were of normal } \\
\text { concrete of } 250 \mathrm{~kg} / \mathrm{cm}^{2}\end{array}$ & $\begin{array}{l}\text { HZ stirrups } \\
\text { at joint }\end{array}$ & Reference Specimen \\
\hline A-2 & $\begin{array}{l}\text { All parts were of normal } \\
\text { strength of } 250 \mathrm{~kg} / \mathrm{cm}^{2}\end{array}$ & $\begin{array}{l}\text { Inclined } \\
\text { stirrups }\end{array}$ & $\begin{array}{l}\text { To study effect of } \\
\text { inclined stirrups }\end{array}$ \\
\hline A-3 & $\begin{array}{l}\text { All parts were of high strength } \\
\text { concrete of grade } 700 \mathrm{kgf} / \mathrm{cm}^{2}\end{array}$ & $\begin{array}{l}\text { HZ stirrups } \\
\text { at joint }\end{array}$ & $\begin{array}{c}\text { Reference Specimen of } \\
\text { HSC }\end{array}$ \\
\hline A-4 & $\begin{array}{l}\text { Lower and upper parts of HSC } \\
\text { of grade } 700 \mathrm{kgf} / \mathrm{cm}^{2}, \text { Middle } \\
\text { part of normal strength } \\
\text { concrete of grade } 250 \mathrm{~kg} / \mathrm{cm}^{2} .\end{array}$ & $\begin{array}{l}\text { Horizontal } \\
\text { stirrups at } \\
\text { the joint }\end{array}$ & $\begin{array}{c}\text { To study effect of } \\
\text { change of concrete } \\
\text { grade at joint compared } \\
\text { to A-3\& A-4 }\end{array}$ \\
\hline A-5 & The same as specimen A-4 & $\begin{array}{l}\text { Inclined and } \\
\mathrm{HZ} \text { stirrups } \\
\text { at the joint }\end{array}$ & $\begin{array}{l}\text { To study effect of } \\
\text { inclined stirrups on the } \\
\text { joint compared to A-4 }\end{array}$ \\
\hline A-6 & $\begin{array}{l}\text { Lower and upper parts of HSC } \\
\text { of grade } 900 \mathrm{kgf} / \mathrm{cm}^{2}, \text { Middle } \\
\text { part of normal strength } \\
\text { concrete of grade } 250 \mathrm{~kg} / \mathrm{cm}^{2} .\end{array}$ & $\begin{array}{l}\text { Horizontal } \\
\text { stirrups at } \\
\text { the joint }\end{array}$ & $\begin{array}{l}\text { To study the effect of } \\
\text { change the strength of } \\
\text { concrete at joint } \\
\text { compared to A-1 \& A-4 }\end{array}$ \\
\hline A-7 & The same as specimen A-6 & $\begin{array}{l}\text { Inclined and } \\
\mathrm{HZ} \text { stirrups } \\
\text { at the joint. }\end{array}$ & $\begin{array}{c}\text { To study effect of } \\
\text { inclined stirrups on the } \\
\text { joint compared to A-6 }\end{array}$ \\
\hline A-8 & $\begin{array}{c}\text { Lower part of HSC } 900 \\
\mathrm{kgf} / \mathrm{cm}^{2}, \text { Middle part of normal } \\
\text { strength } 250 \mathrm{kgf} / \mathrm{cm}^{2}, \text { Upper } \\
\text { part of HSC of } 500 \mathrm{kgf} / \mathrm{cm}^{2}\end{array}$ & $\begin{array}{l}\text { Horizontal } \\
\text { stirrups at } \\
\text { the joint }\end{array}$ & $\begin{array}{l}\text { To study effect of } \\
\text { change of grade below } \\
\text { and above the joint } \\
\text { compared to A-1 \&A-6 }\end{array}$ \\
\hline A-9 & The same as specimen A-8 & $\begin{array}{l}\text { and } \\
\text { ups. }\end{array}$ & $\begin{array}{l}\text { Study effect of inclined } \\
\text { stirrups compared to A-8 }\end{array}$ \\
\hline A-10 & $\begin{array}{l}\text { Lower part of HSC of grade } \\
500 \mathrm{kgf} / \mathrm{cm}^{2}, \text { Middle part of } \\
\text { normal strength concrete of } \\
\text { grade } 250 \mathrm{kgf} / \mathrm{cm}^{2}, \text { Upper part } \\
\text { of } \mathrm{HSC} \text { of grade } 900 \mathrm{kgf} / \mathrm{cm}^{2}\end{array}$ & $\begin{array}{l}\text { Horizontal } \\
\text { stirrups at } \\
\text { the joint }\end{array}$ & $\begin{array}{l}\text { Study effect of using } \\
\text { lower grade below the } \\
\text { joint relative to the } \\
\text { grade of upper part, } \\
\text { compared to A-1 \& A-8 }\end{array}$ \\
\hline A-11 & $\begin{array}{l}\text { Lower part of HSC of grade } \\
700 \mathrm{kgf} / \mathrm{cm}^{2}, \text { Middle part of } \\
\text { normal strength concrete of } \\
\text { grade } 250 \mathrm{kgf} / \mathrm{cm}^{2}, \text { Upper part } \\
\text { of normal grade } 250 \mathrm{kgf} / \mathrm{cm}^{2}\end{array}$ & $\begin{array}{l}\text { Horizontal } \\
\text { stirrups at } \\
\text { the joint }\end{array}$ & $\begin{array}{l}\text { Study the effect of } \\
\text { using HSC below the } \\
\text { joint. the upper part has } \\
\text { the same normal } \\
\text { strength as joint, } \\
\text { compared to A-1. }\end{array}$ \\
\hline A-12 & The same as specimen A-12 & $\begin{array}{l}\text { Inclined and } \\
\mathrm{HZ} \text { stirrups } \\
\text { at the joint. }\end{array}$ & $\begin{array}{l}\text { Study effect of inclined } \\
\text { stirrups on the joint } \\
\text { compared to A-11 }\end{array}$ \\
\hline
\end{tabular}




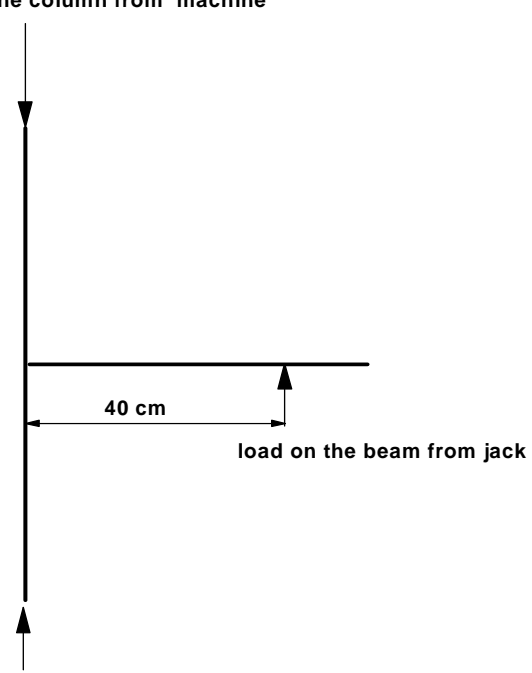

Fig. 2 (a): System of loading

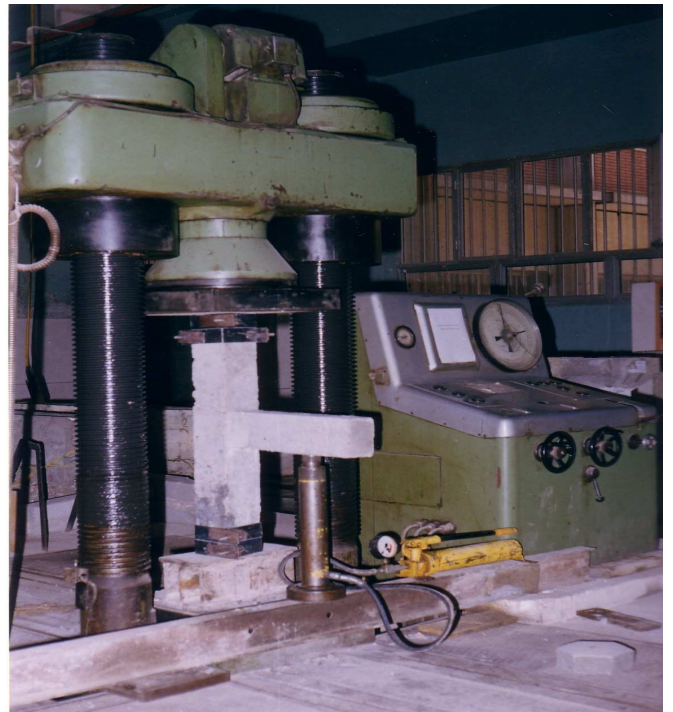

Fig. 2 (b): Test setup
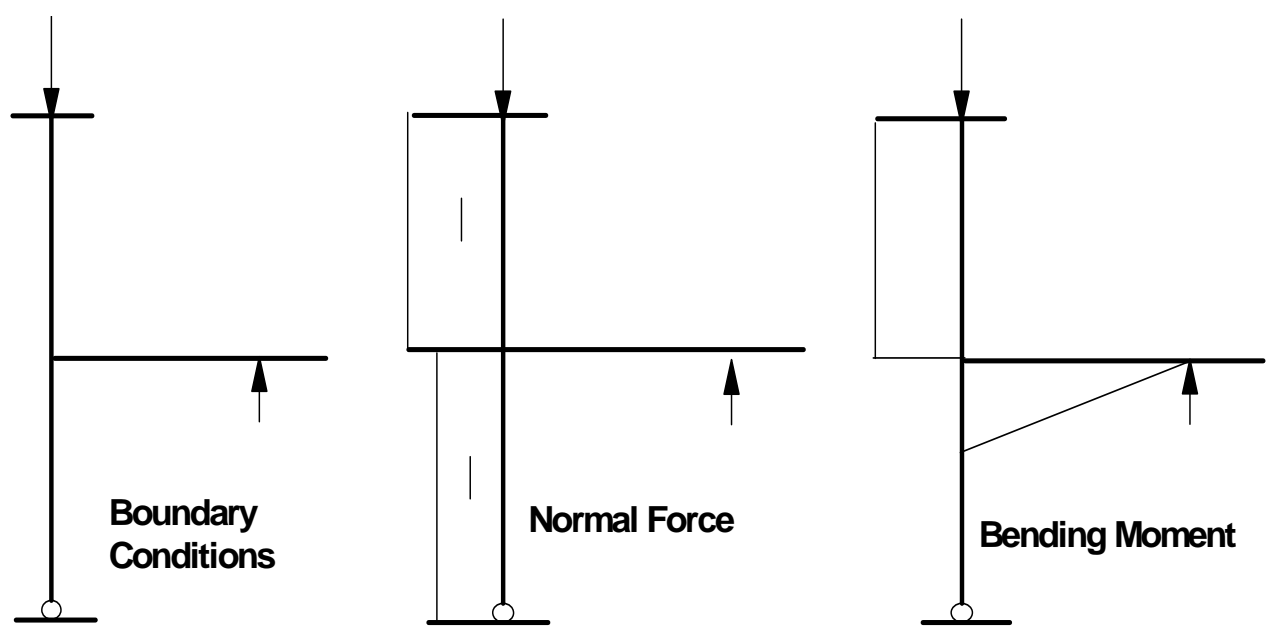

Fig. 3: Boundary conditions and straining actions of test specimen.

\section{RESULTS AND ANALYSIS}

\section{Failure Mode}

Photos 1 to 12 illustrate the final failure modes of specimens A-1 to A-12, respectively. By investigating the failure mode of specimens, the following points are summarized:

1- Both of specimens A-1 and A-2 have the same failure mode at the upper part of the column. Concrete cover has spalled out and this extends from the top until the joint as it is clear from photos 1 and 2. The role of inclined stirrups at the joints is not significant on changing the failure mode in such specimens of normal strength concrete. 
2- Specimen A-3 of HSC at all the parts has the same failure mode. No collapse occurred at the joint. Concrete cover has spalled out in the upper part and this extends from the top until the joint as shown in photo 3 .

3- In specimens A-4 and A-5, failure occurs at the joint of normal strength concrete as it is clear in photos 4 and 5. However, the inclined stirrups at joint of specimen A-5 prevented the bucking of longitudinal bars of the column.

4- In specimens A-6, A-7, A-8, A-9 and A-10, failure occurred at the joint of each specimen due to the normal strength concrete as shown in photos $6,7,8,9$ and 10 . The inclined stirrups at joints of specimens A-7 and A-9 have neglected effect on failure mode, however they reduced the bucking phenomenon of steel bars.

5- Both of specimens A-11 and A-12 have the same failure mode at the upper part of the column as shown in photos 11 and 12 noting that the middle part and upper part of the columns are constructed from normal strength concrete. Concrete cover has spalled out and this extends from the top until the joint.

From such discussion we conclude that, failure occurs at the joints of normal strength concrete. Consequently, special arrangement of steel reinforcement is needed to prevent such failure. The inclined stirrups are not sufficient to change the failure mode.

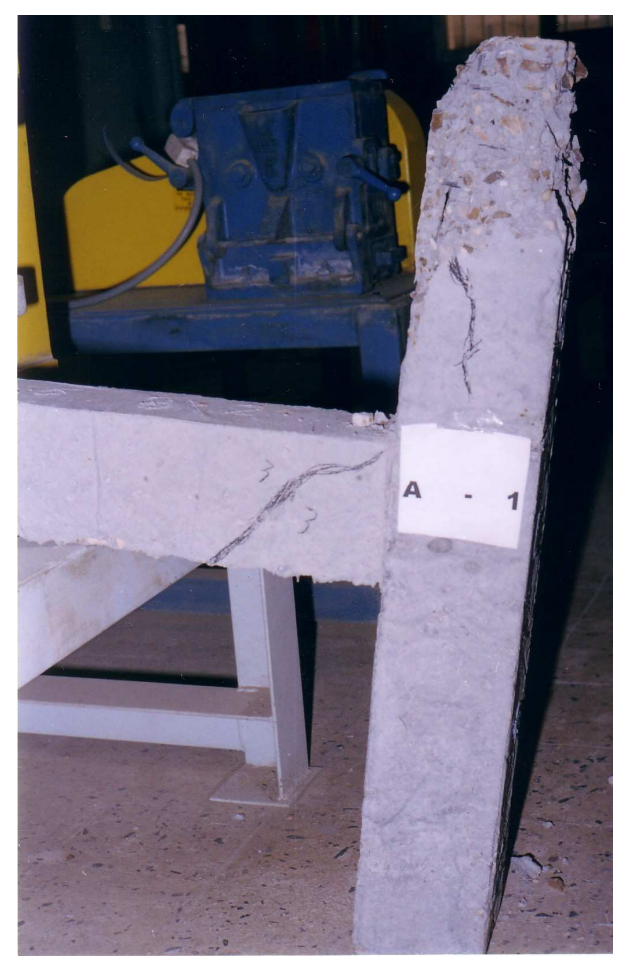

Photo 1

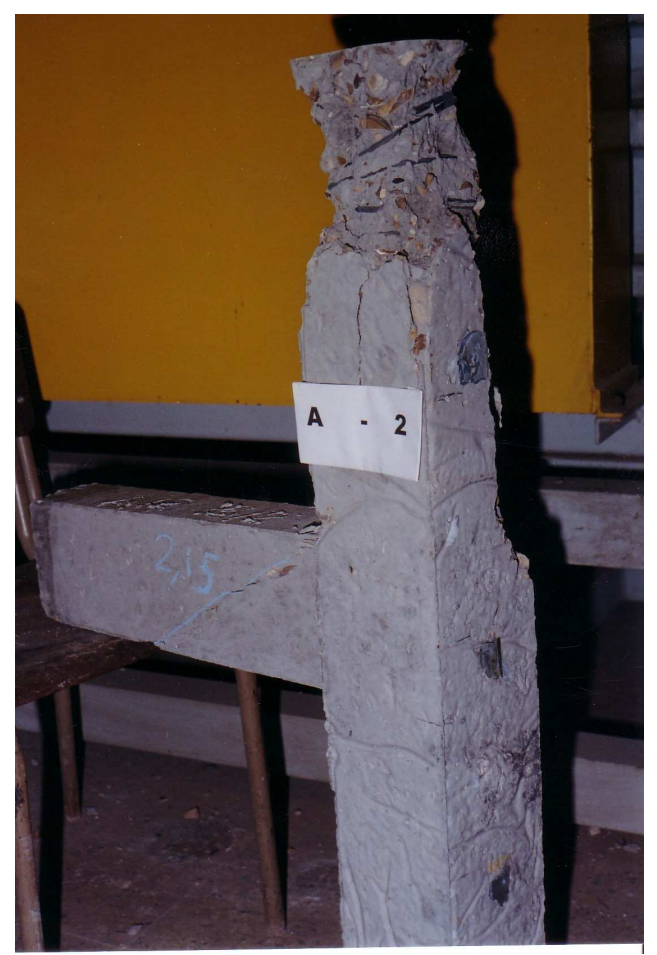

Photo 2 


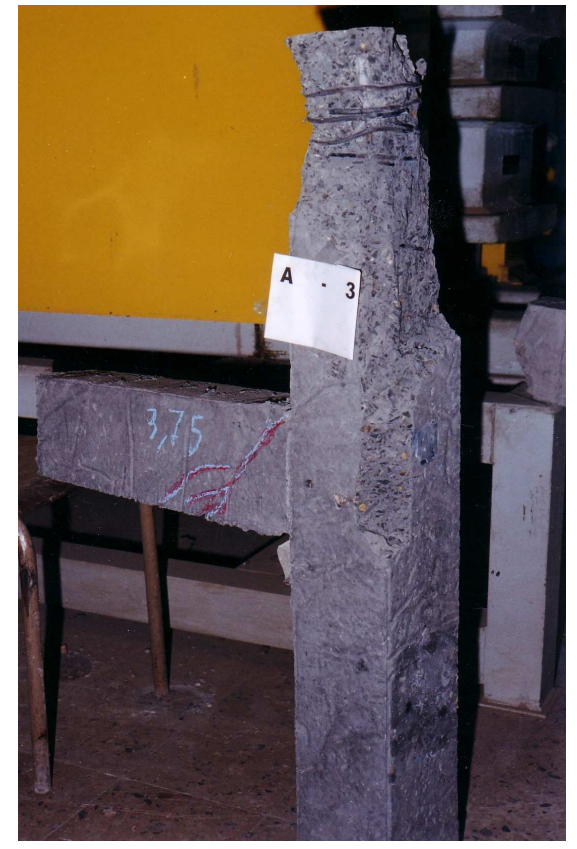

Photo 3

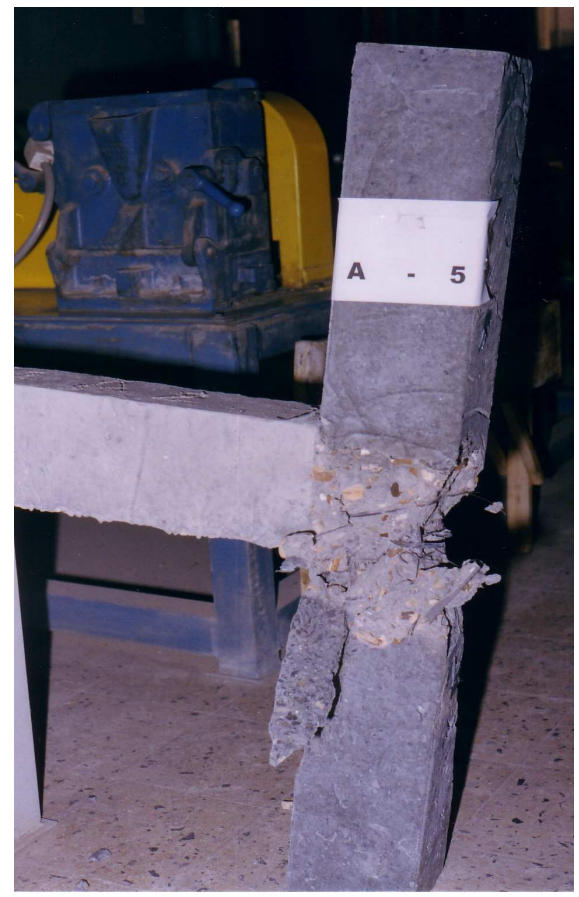

Photo 5

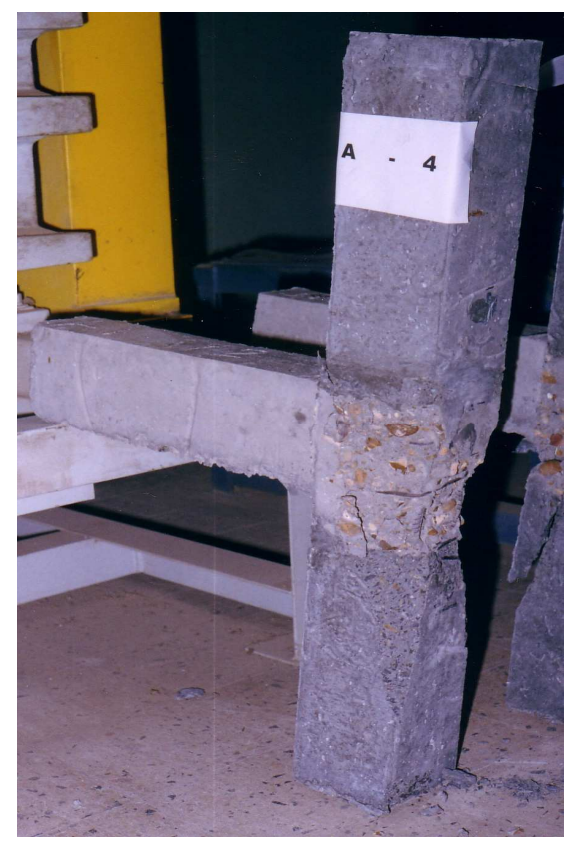

Photo 4

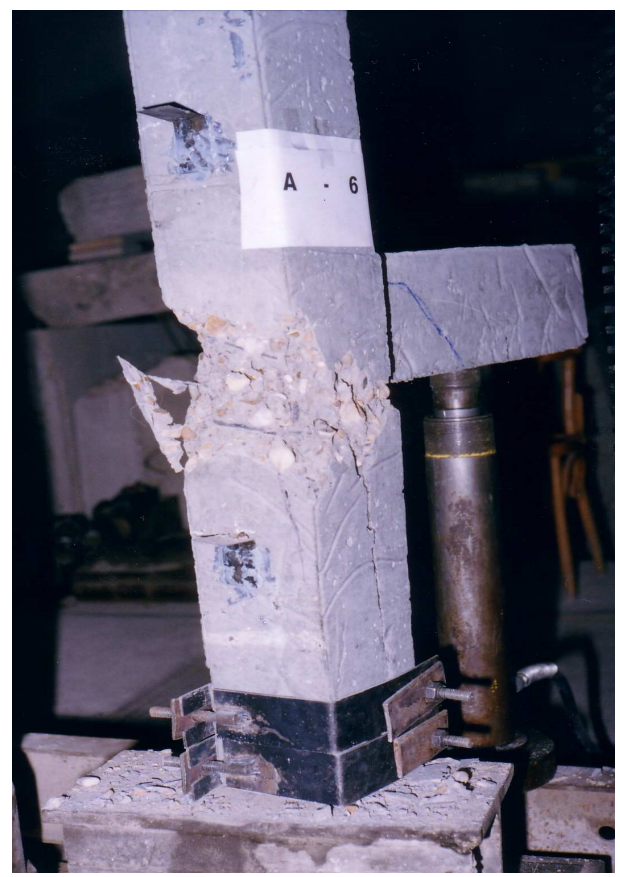

Photo 6 


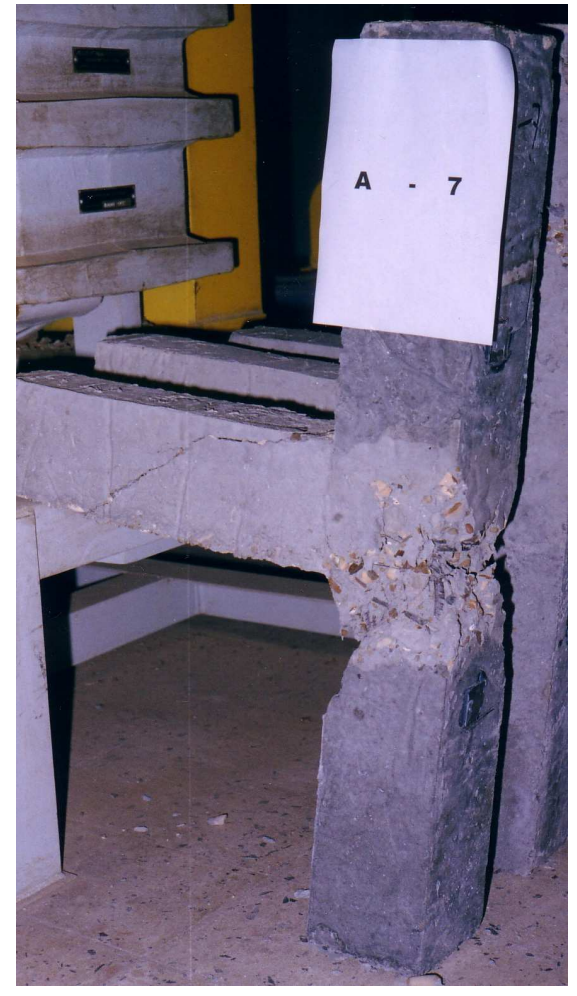

Photo 7

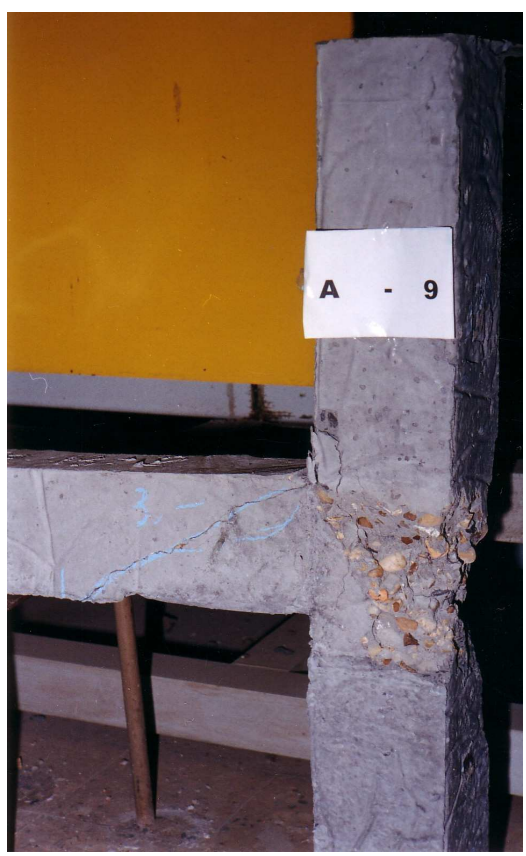

Photo 9

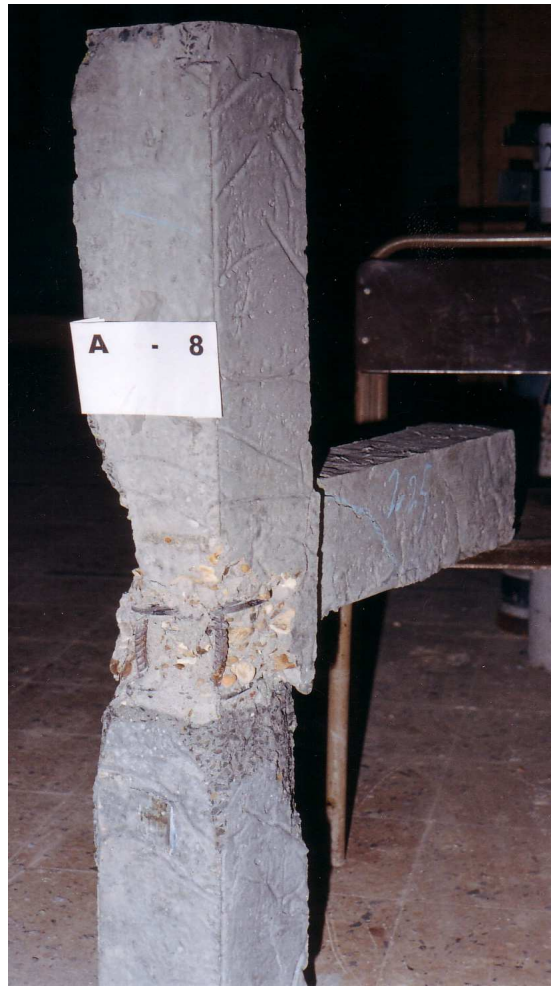

Photo 8

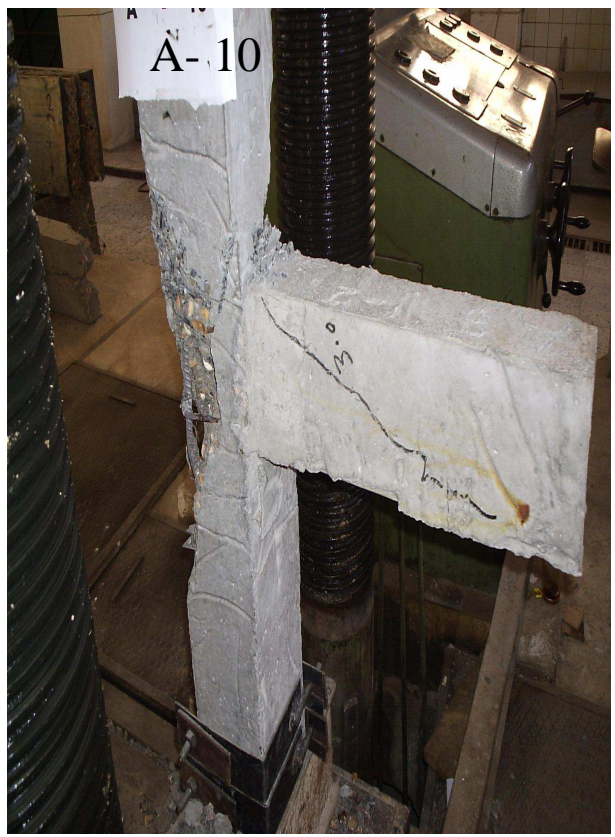

Photo 10 


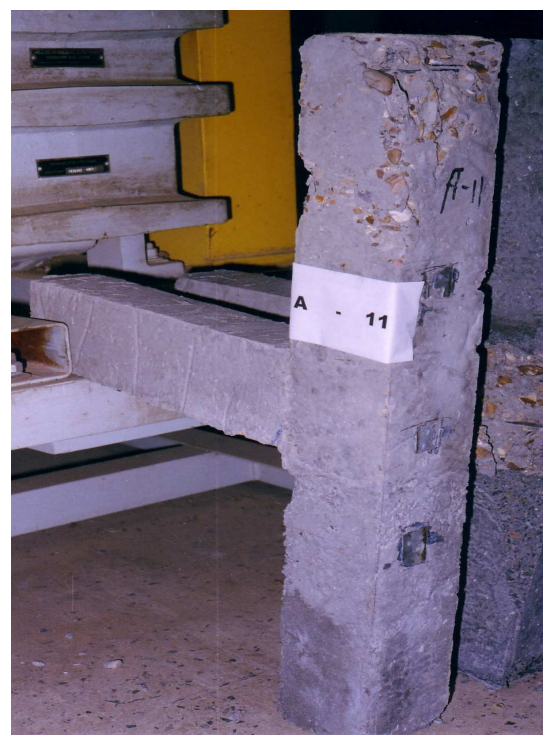

Photo 11

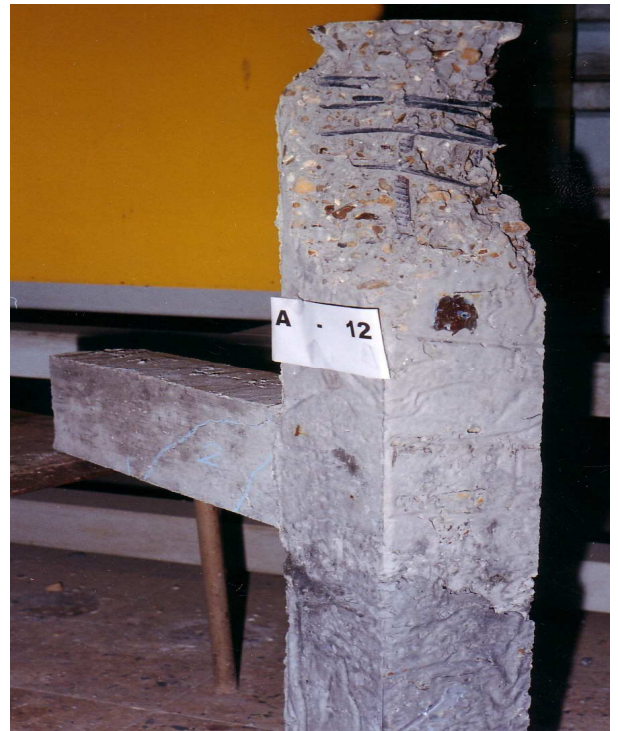

Photo 12

\section{2- Relationships of Axial Load and Strain}

The axial longitudinal strain of the column was measured at three points; Point 1 above of the joint, Point 2 inside the joint (distance between point 1 and 2 is $22.5 \mathrm{~cm}$ ) and the mean axial strain all over the height, noting that the movable head of the testing machine is the lower one. Figure 4 illustrates the positions of the measured strains. Figure 5 illustrates the relationships between axial load of the column and the measured strain at points 1,2 and the mean axial strain for specimens A-1 to A-12 respectively. By investigating the curves, it is clear that the strain at point 1 is usually less than that at point 2 . This is because that strain at point 2 is affected by the rotation of the joint due to bending moment and shear on the beam. The stress at point 1 is mainly due to compression and moment while the effect of the joint rotation is minimum. For this reason, the strain at point 1 is close to the mean axial strain for most
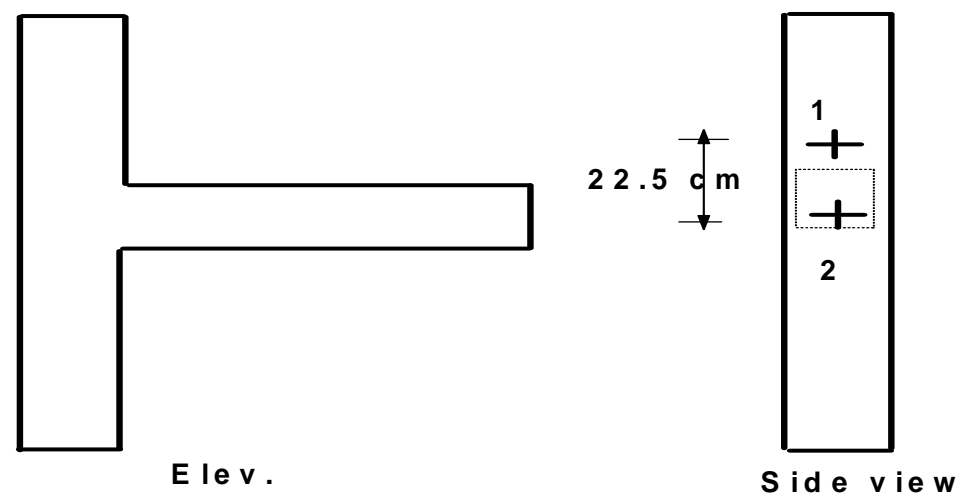

Fig. 4: Positions of the Measured Strain. 
of the columns. So, failure occurred at the lower face of the joint at most of the specimens. Comparing the mean axial strain with the yield strain of main steel of the column (which is approximately about $3.8 \times 10^{-3}$ for steel 36/52), we can see that yielding of main steel of the column occurred first before crushing of concrete for all specimens.
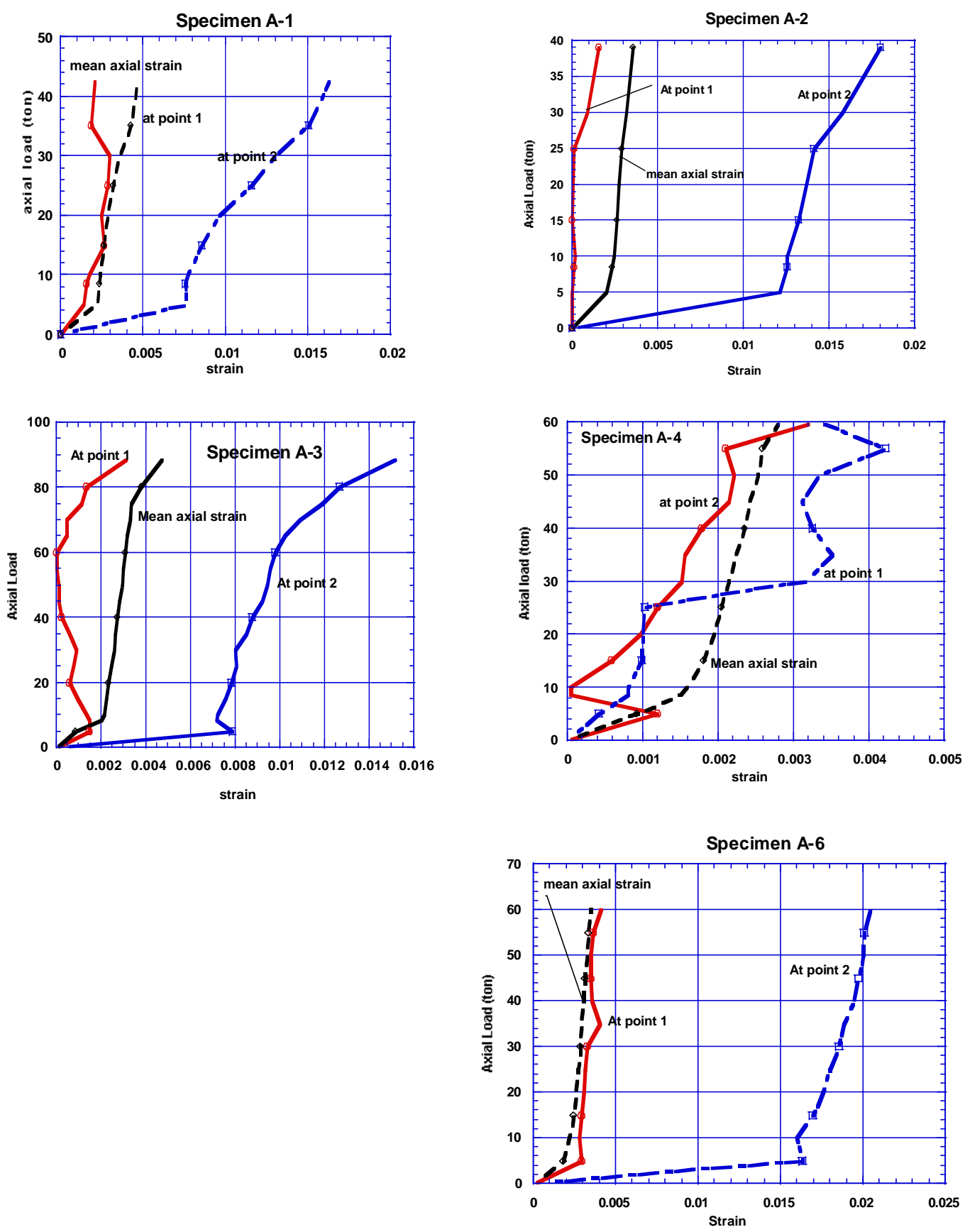

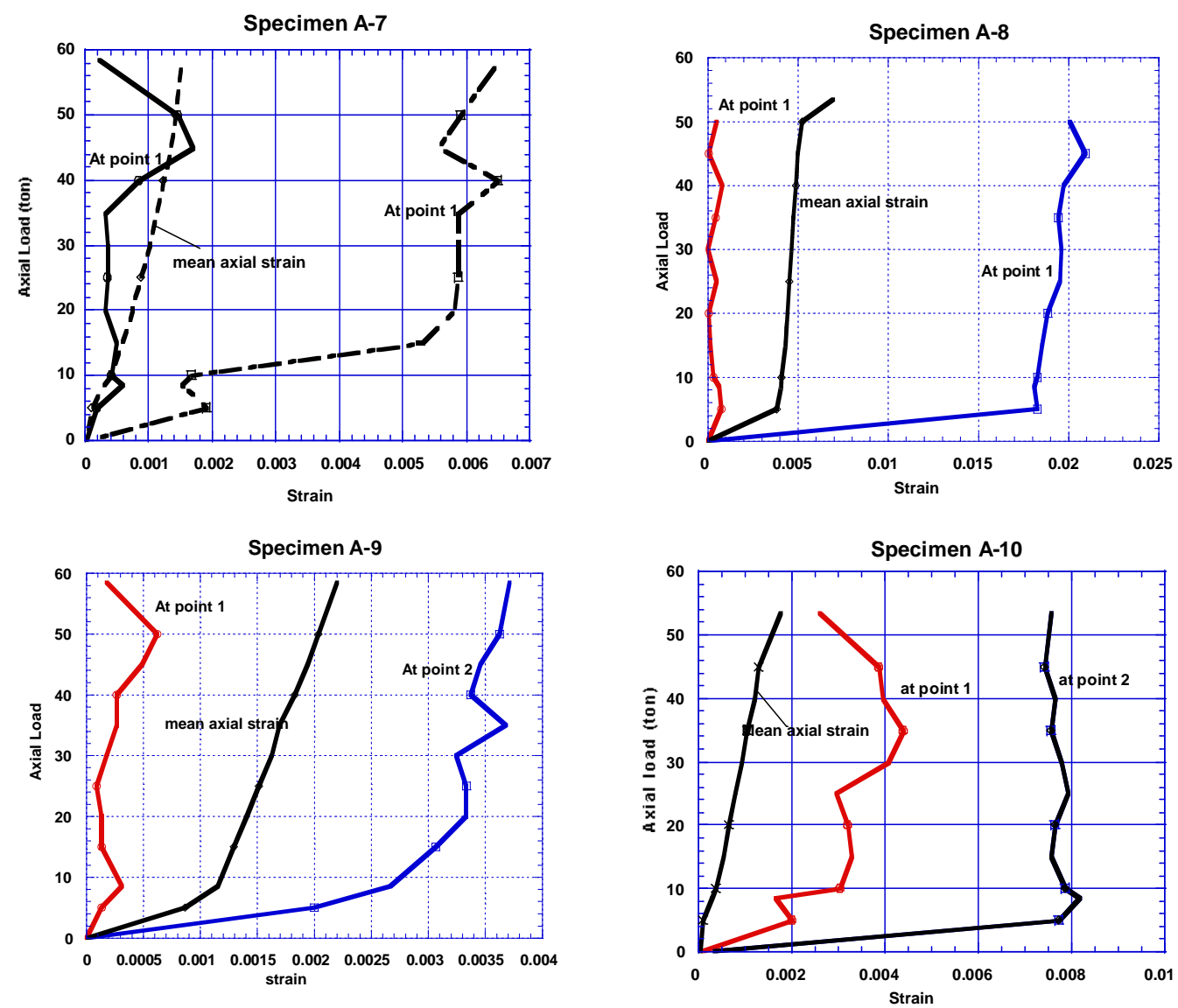

Fig. 5: Relations of axial load of the column and strain for specimens A-1 to A-12.

\section{3- Ultimate Load}

Figure 6 illustrates the graph of the ultimate load of columns of specimens. Table 4 illustrates the ultimate load of the columns and the cracking load of the beams for different specimens.

By investigating the results in Fig. 6 and Table 4, the following points are summarized:

1- Specimens A-1 and A-2 have the same properties except that specimen A-2 has two inclined stirrups at the joint. Ultimate load of specimen A-2 is higher than that of A-1 and the difference is 6.0 ton with the rate of increase equals $14.1 \%$. The inclined stirrups at joint has significant influence on the strength. The beams of the two specimens have the same diagonal shear failure. The joint of specimen A-2 is stronger than that of specimen A-1, and hence the cracking load of the beam of A-2 is less than that of A-1.

2- Specimen A-3 is of HSC of grade C700. Ultimate load of the column is 89 tons. The increase of the load relative to specimen A-1 is 46.5 tons with the rate of increase equals $109.4 \%$. The cracking load of beam is 3.75 tons with the rate of increase relative to A-1 equals $25 \%$ which is lower than the rate of increase of ultimate load of the column. This is due to the higher degree of brittleness of HSC relative to the normal strength. 


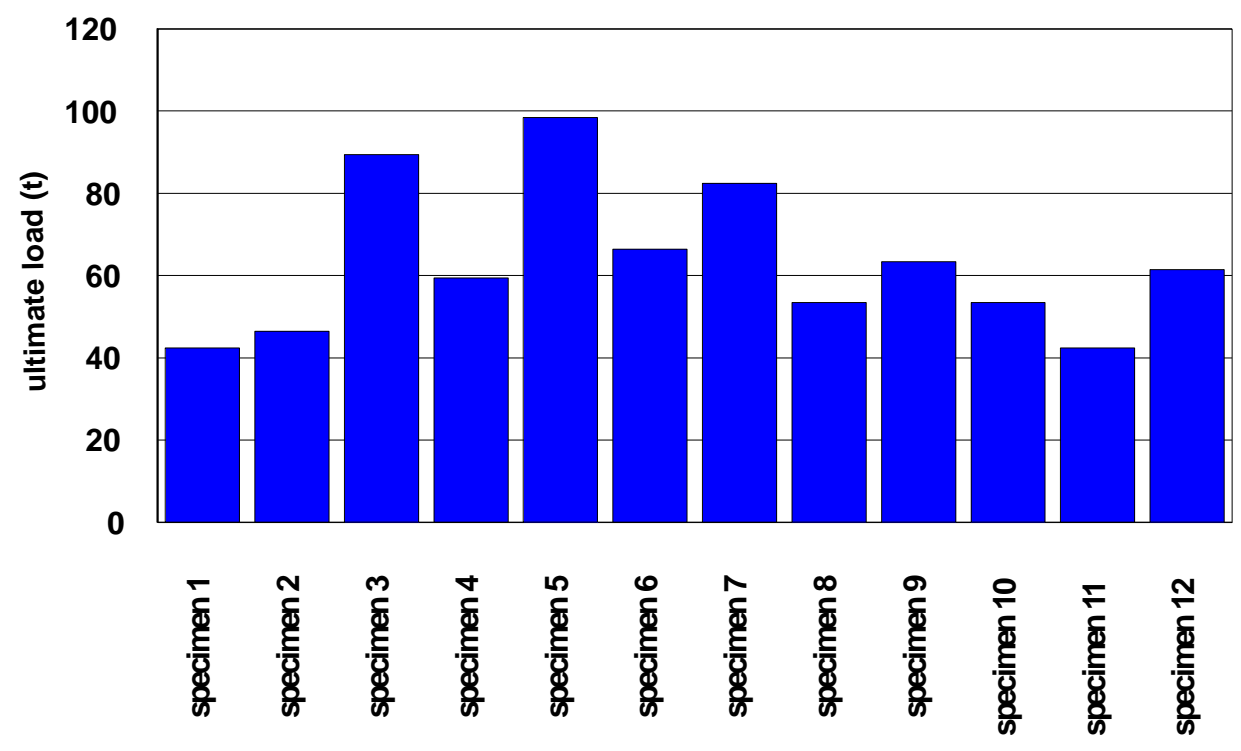

Fig. 6: Graph of the ultimate load of specimens.

Table 4: Ultimate load of columns and cracking load of beams.

\begin{tabular}{|c|c|c|c|c|c|c|c|c|c|c|c|c|}
\hline Sp. No. & A-1 & A-2 & A-3 & A-4 & A-5 & A-6 & A-7 & A-8 & A-9 & A10 & A11 & A-12 \\
\hline Column load (t) & 42.5 & 48.5 & 89 & 59.5 & 98.5 & 66.5 & 82.5 & 53.5 & 63.5 & 53.5 & 46.5 & 61.5 \\
\hline $\begin{array}{c}\text { Beam Crack. load } \\
\text { (t) }\end{array}$ & 3.0 & 2.25 & 3.75 & 2.5 & 2.0 & 2.5 & 2 & 2.1 & 3.05 & 2.5 & 2.5 & 2 \\
\hline
\end{tabular}

3- Specimen A-4 has HSC at the lower and upper parts of the column of grade C700. The joint and the beam are of normal strength concrete. The specimen has the same horizontal stirrups such as specimens A-1 and A-3. Ultimate load is 59.5 tons which is higher than that of specimen A-1 with the rate of $40 \%$. However, the ultimate load of specimen A-4 is less than that of specimen A-3 with the rate of reduction equals 32.6 tons. The increase of the ultimate load relative to specimen A-1 is due to the HSC and the reduction of the load relative to specimen A-3 is due to the lower concrete strength of the joint. To increase the ultimate load of such specimen, special steel arrangement is needed as it clear in specimen A-5. Inclined stirrups cause an increase in the shear strength of the columns and hence the ultimate load of column increases.

4- Specimen A-5 is exactly the same as specimen A-4 except that specimen A-5 has two inclined stirrups at the joint. Ultimate load is 98.5 tons with rate of increase relative to specimen A-4 equals $65.5 \%$. The rate of increase relative to specimen A-1 is $131.8 \%$. The ultimate load is approximately the same as specimen A-3. The role of inclined stirrups in case of HSC (A-4 and A-5) is more significant than that in case of normal strength concrete (A-1 and A-2). This is a very significant conclusion from the study. 
5- Specimen A-6 has HSC at the lower and upper parts of the column of grade C900. The joint and the beam are of normal strength concrete. The specimen has the same horizontal stirrups such as specimens A-1 and A-3. Ultimate load is 66.5 tons which is higher than that of specimen A-1 with the rate of $56.5 \%$. However, the ultimate load of specimen A-6 is higher than that of specimen A-4 with the rate of increase equals $11.8 \%$. This means that the gain of strength with increase of the grade of concrete is not so significant. The increase of the ultimate load relative to specimen A-1 is due to the HSC and the low rate of increase relative to A-4 is due to the lower concrete strength of joint.

6- Specimen A-7 is exactly the same as specimen A-6 except that specimen A-7 has two inclined stirrups at the joint. Ultimate load is 82.5 tons with rate of increase relative to specimen A-6 equals $24 \%$. The rate of increase relative to specimen A1 is $95 \%$. The role of inclined stirrups in such case of HSC (specimens A-6 and A7) is much more significant than that in case of normal strength concrete as it is clear from specimens A-1 and A-2. This agrees with the same conclusion of specimens A-4 and A-5.

7- Specimen A-8 has HSC of grade C900 at the lower part and HSC of grade C500 at the upper part of the column. The joint and the beam are of normal strength. The specimen has the same $\mathrm{HZ}$ stirrups as specimens A-1 and A-3. Ultimate load is 53.5 tons which is higher than that of A-1 with the rate of $25.9 \%$. However, ultimate load of A-6 is less than that of A-6 with rate of decrease of $19.5 \%$. This is due to the lower grade of upper part of the column. The variation of HSC grades leads to reduction of ultimate load.

8- Specimen A-9 is exactly the same as specimen A-8 except that specimen A-9 has two inclined stirrups at the joint. Ultimate load is 63.5 tons with rate of increase relative to specimen A-8 equals $18.7 \%$. The rate of increase relative to specimen A-1 is $49.4 \%$. Again the inclined stirrups have significant influence on increasing the ultimate load.

9- Specimen A-10 has HSC of grade C500 at the lower part and HSC of grade C900 at the upper part of the column. The joint and the beam are of normal strength concrete. The specimen has the same HZ stirrups such as A-1. Ultimate load is 53.5 tons which is higher than that of specimen A-1 with the rate of $23.5 \%$. However, the ultimate load of specimen A-10 equals to that of specimen A-8. The purpose of specimens A-8, A-9 and A-10 is to study the effect of variation of concrete strength at the parts of the column.

10- Specimen A-11 has HSC of grade C700 at the lower part and normal strength of grade $\mathrm{C} 250$ at the upper part of the column, joint and the beam. The specimen has the same HZ stirrups such as A-1. Ultimate load is 46.5 tons which is higher than that of specimen A-1 with the rate of $9.4 \%$. A negligible gain in the ultimate load is obtained by using HSC at lower part of column only while the other parts have normal concrete.

11- Specimen A-12 is exactly the same as specimen A-11 except that specimen A-12 has two inclined stirrups at the joint. Ultimate load is 61.5 tons with rate of increase relative to specimen A-11 equals $32.5 \%$. The rate of increase relative to specimen A-1 is $44.7 \%$. Again the inclined stirrups have significant influence on increasing the ultimate load. 


\section{Strength of the Column}

As it was mentioned, in high rise buildings, columns are usually constructed with high strength concrete to make cross sectional area smaller. However, floor slabs and beams are usually constructed with normal strength concrete to meet the flexural requirements. This leads to a question: How can the forces from a column with HSC be transmitted through a floor beams with normal strength concrete?. In another way, which concrete grade is used to estimate the ultimate strength of the column? Is it the high concrete strength of the column parts or the normal concrete strength of the joint?. Egyptian Code does not include how to estimate strength of HSC columns. ACI Code gives the following equation [5,7] to estimate the strength of the axially loaded columns

$$
P_{o}=A_{s t} f_{y}+\left(A_{g}-A_{s t}\right) 0.85 f_{c}^{\prime}
$$

Where, $P_{o}=$ nominal strength of axially loaded reinforced concrete column, $\mathrm{A}_{\mathrm{st}}=$ total area of longitudinal reinforcement bars in the column, $f_{y}, f_{c}$ are yield stress of steel and compressive strength of concrete respectively and $\boldsymbol{A}_{g}=$ gross area of column cross section. Concrete strength in Eq. (1) is the strength of standard cylinder. The factor 0.85 is used for the variation of test results used to calculate the cylinder strength. Again, the problem is which $f_{c}$ is used?. We will try to define a factor instead of 0.85 in Eq. (1) and we will use the cube strength instead of cylinder strength. The suggested equation is:

$$
P=\frac{A_{s} f_{y}}{1.15}+K\left(A_{c}-A_{s}\right) f_{c}
$$

Where, $\mathrm{P}=$ nominal strength of axially loaded column

As $=$ total area of longitudinal reinforcement bars in the column

$f_{y}, f_{c}$ are yield stress of steel and compressive cube strength of concrete respectively, $\boldsymbol{A}_{\boldsymbol{c}}$ is the gross area of the column cross section and

$\boldsymbol{K}$ is the strength coefficient which depends on concrete strength and steel arrangement

Tables 5 and 6 illustrate the strength coefficient K of Eq. 2 for specimens without inclined stirrups and with inclined stirrups respectively for two cases as follows:

Case 1: normal concrete strength of the joint is used in Eq. 2

Case 2: HSC concrete is used in the Eq. 2 (In some specimens there two grades of HSC)

Table 5: Strength coefficient (K) of Eq. 2 for specimens without inclined stirrups.

\begin{tabular}{|c|c|c|c|c|c|c|c|c|}
\hline \multicolumn{2}{|c|}{ Specimen } & $\mathbf{A - 1}$ & $\mathbf{A - 3}$ & $\mathbf{A - 4}$ & $\mathbf{A - 6}$ & $\mathbf{A - 8}$ & $\mathbf{A - 1 0}$ & $\mathbf{A - 1 1}$ \\
\hline \multicolumn{2}{|c|}{ Ultimate load } & 42.5 & 89 & 59.5 & 66.5 & 53.5 & 53.5 & 61.5 \\
\hline \multirow{2}{*}{$\begin{array}{c}\text { Strength } \\
\text { coefficient K K }\end{array}$} & Case 1 & 0.57 & - & 0.82 & 0.94 & 0.71 & 0.71 & 0.82 \\
\cline { 2 - 9 } & Case 2 & - & 0.57 & 0.294 & 0.26 & $\begin{array}{c}0.2 * \\
0.36 * *\end{array}$ & $0.2 *$ & $0.36 * *$ \\
\end{tabular}

* Coefficient relative to C900 *** coefficient relative to C500 
Table 6: Strength coefficient (K) of Eq. 2 for specimens with inclined stirrups.

\begin{tabular}{|c|c|c|c|c|c|c|}
\hline \multicolumn{2}{|c|}{ Specimen } & $\mathbf{A - 2}$ & $\mathbf{A - 5}$ & $\mathbf{A - 7}$ & $\mathbf{A - 9}$ & $\mathbf{A - 1 2}$ \\
\hline \multicolumn{2}{|c|}{ Ultimate load } & 42.5 & 98.5 & 59.5 & 66.5 & 53.5 \\
\hline \multirow{2}{*}{$\begin{array}{c}\text { Strength } \\
\text { coefficient K }\end{array}$} & Case 1 & 0.85 & 1.53 & 1.24 & 0.9 & 1.09 \\
\cline { 2 - 7 } & Case 2 & & 0.54 & 0.35 & $\begin{array}{c}0.25 * \\
0.45 * *\end{array}$ & 0.39 \\
\hline
\end{tabular}

* Coefficient relative to C900 ** coefficient relative to C500

In Tables 5 and 6, Case 1 is related to normal strength concrete of joint. Case 2 is related to concrete grade $\mathrm{C} 700$ except those assigned with $*$ and $* *$.

From such analyses, the following points are concluded:

1- If the column has the same strength all over its parts including the joint, then:

Strength coefficient $\mathrm{K}$ is the same for the columns of the same concrete strength either normal strength or high strength as follows:

$\mathrm{K}=0.57$ if the joint has horizontal stirrups as the rest of the column.

$\mathrm{K}=0.85$ if the joint has inclined stirrups (Inclined stirrups cause an increase in the shear strength of column and hence ultimate load of the column increases, so $\mathrm{K}$ increases)

2- If the column has HSC on its parts except the joint which has normal strength then:

$\mathrm{K}=0.8$ if the normal strength is used in Eq. 2 and the joint has HZ stirrups only

$\mathrm{K}=0.28$ if the HSC is used in Eq. 2 and the joint has horizontal stirrups only

$\mathrm{K}=1.19$ if the normal strength is used in Eq. 2 and the joint has inclined stirrups.

$\mathrm{K}=0.4$ if the HSC is used in Eq. 2 and the joint has inclined and HZ stirrups.

\section{CONCLUSIONS AND REMARKS}

1- An experimental study was carried out to investigate the effect of changing the grade of concrete on the behavior of RC column and its joint considering the interaction of the column with the floor beams. Floor beams and the joint are constructed from normal strength concrete, while the other parts of the column below and above the joint are constructed using different grades of high strength and normal strength concretes. The study included the effect of the details of reinforcement of the joint represented by horizontal or inclined stirrups. Twelve specimens of RC columns and intersecting beams are prepared and tested under compressive loading on the column and vertical load on beam.

2- It has been found that failure mode of such structures occurs at the joint because of its low strength which has been constructed with the floor beams. The inclined stirrups at joints do not change the failure mode even it reduces its severity. Other steel arrangement is still needed to change the failure mode.

3- Inclined stirrups have significant influence on increasing the ultimate strength of the columns. This is because the inclined stirrups cause an increase on the shear strength of the column resulting in the increase of the column strength. 
4- The strain distribution is highly affected by the interaction of beam and the column. Maximum strain occurred at the joint due to combined state of stress from the axial load of the column and bending moment and shearing force on the beam.

5- An equation was deduced to estimate the strength of axially loaded columns considering the interaction of floor beams, variation of concrete strength and details of reinforcement. The deduced equation takes the following form:

$$
P=\frac{A_{s} f_{y}}{1.15}+K\left(A_{c}-A_{s}\right) f_{c}
$$

The strength coefficient $\mathbf{K}$ in the equation takes the following values:

A- For the columns of the same concrete strength either normal strength or HSC:

$\mathrm{K}=0.57$ if the joint has horizontal stirrups, $\mathrm{K}=0.85$ if the joint has inclined stirrups

B- For columns of HSC above and/or below the joint but the joint has normal strength:

$\mathrm{K}=0.8$ if the normal strength of the joint is used and the joint has $\mathrm{HZ}$ stirrups only

$\mathrm{K}=0.28$ if the HSC is used in the equation and the joint has horizontal stirrups only

$\mathrm{K}=1.19$ if the normal strength is used and the joint has inclined stirrups.

$\mathrm{K}=0.4$ if the HSC is used in Eq. 2 and the joint has inclined and horizontal stirrups.

The deduced equation is applicable to normal strength concrete and high strength concrete and it is recommended to be used in future design of such structural elements.

\section{REFERENCES}

[1] NRMCA "Concrete in Practice, What, Why, How" National ready Mixed Concrete Association, www.nrmca.org

[2] Sofia M.and Dan M. " Strength and Ductility Simulation of High-Strength Concrete Columns” ASCE, Vol.123, Issue 10, October 1997, pp. 1365-1374

[3] Sofia M.and Dan M. "Reliability Bases for High-Strength Concrete Columns" ASCE, Volume 123, Issue 10, October 1997, pp. 1375-1381

[4] Christina C.and Kent G. "Slender High-Strength Concrete Columns Subjected to Eccentric Loading" ASCE, Vol. 124, No. 3, pp. 233-240

[5] William L., et al "Tests of High-Strength Concrete Columns with Intervening Floor slabs' Journal of St. Engineering, Vol.117, No.5, May, 1991, 1462-1476

[6] Marzouk H, et al "Effect of High Strength Concrete Columns on the Behavior of Slab-Column Connections” ACI Structural Journal, Vol. 93, No.5, Sept.1996

[7] ACI Building Code, 1989

[8] Amr Abdelrahman "Behavior of Concrete corbels Strengthened by FRP Laminates" port Said Eng. Research J., Suez Canal Univ., vol.9, 2, Sept. 2002

[9] Fadel A., et al "A study on High Strength Connections Subject to Inelastic Cyclic Loading” J. of Str. Engineering, Vol.117, No.3, March.1991, pp.829-850 
[10] Oral buyukozturk, et al "improving the ductility of high performance concrete for structural applications" Structural Engineering World Wide 1998, July 1923, San Francisco, USA, Elsevier publications

[11] Bosco C., et al "Minimum reinforcement in high strength concrete" Journal of Structural Engineering, Vol.116, No.2, Feb.1990, pp.427-437).

[12] Yook K, et al "Behavior of laterally confined high strength concrete under axial loads" Journal of Structural Engineering, Vol.114, No.2, Feb.1988, pp.332-351.

[13] Nakazawa et al "Aconfinement Model of HSC" $13^{\text {th }}$ world Conference on Earthquake Eng., Vancouver, Canada, August 2004, Paper No. 873.

[14] Yan X. and Armen M. "Seismic Performance of High-Strength Concrete Columns" ASCE, Vol. 124, No. 3, pp pp. 241-251.

[15] Takashi K and Hiroshi Noguchi "Shear performance of prestressed RC interior Beam-Column Joints" Reprint from Modeling of Inelastic Behavior of RC structures, Committee report, American Society of Civil Engineers, Original copy from authors.

[16] H.W. Reinhardt, S. Weber "Zero-Curing High performance Concrete" St. Eng. World Wide 1998, July 19-23, San Francisco, Elsevier publications.

[17] Khairy Hassan "Finite Element Study on Shear Behavior of RC Beams with HSC" $1^{\text {st }}$ Int. Conf. of Civil Eng., vol. 1, Assiut Univ., 2003, 835-845.

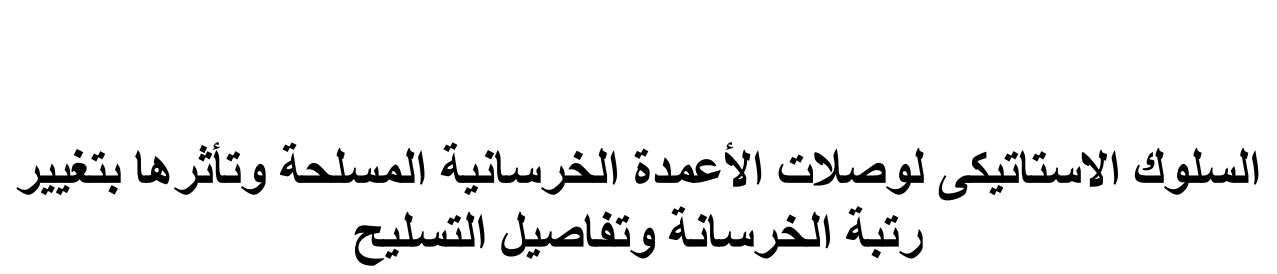

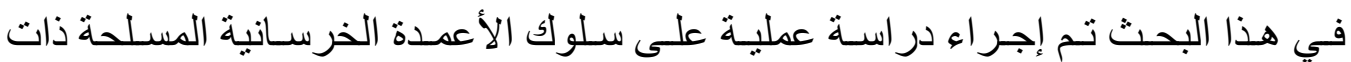

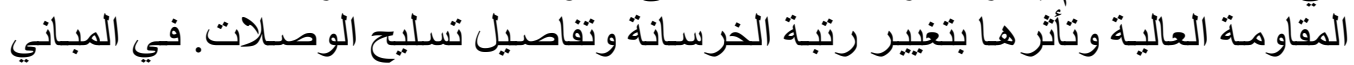

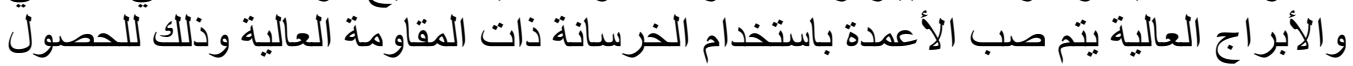

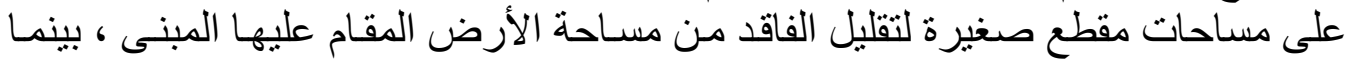

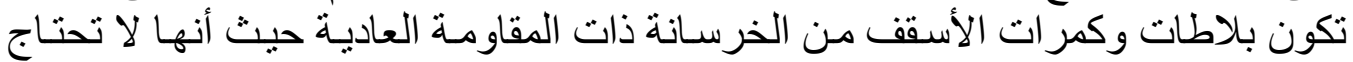

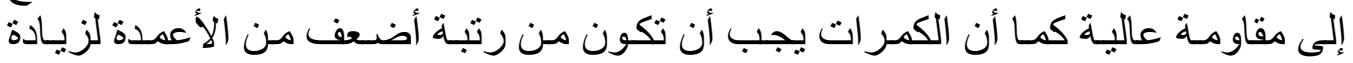

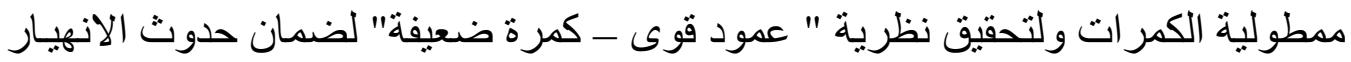

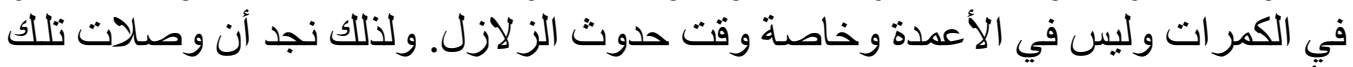

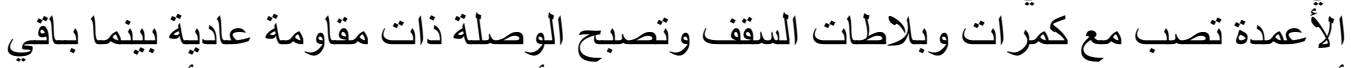

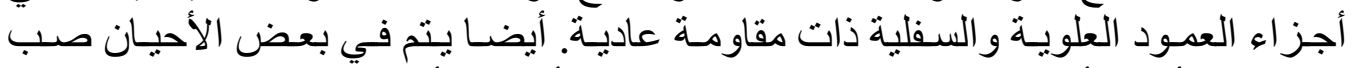

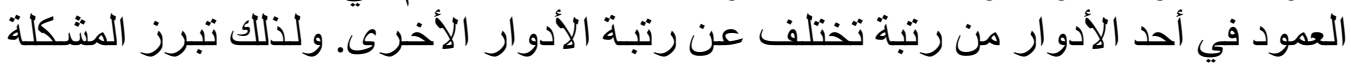

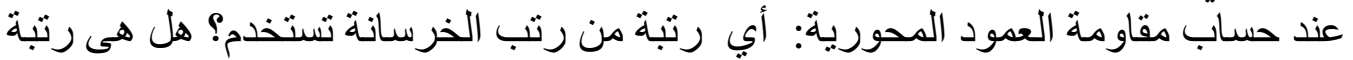

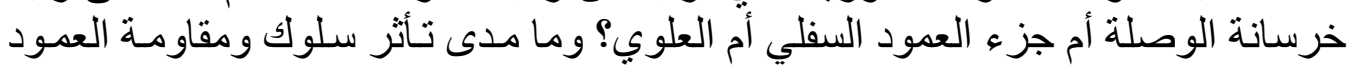

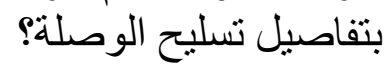


لقد تم صب عدد 14 عينة اختبار من أعمدة وكمرات وتم تغيير رتبة الخرسـانة في أجزاء

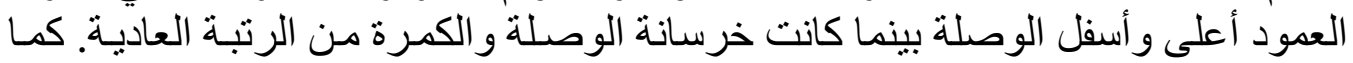

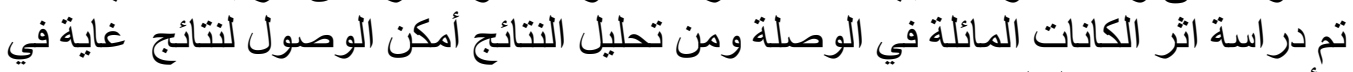

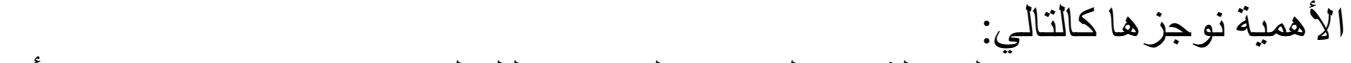

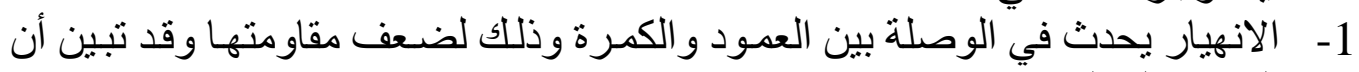

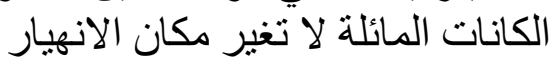

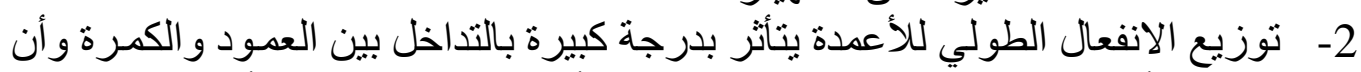

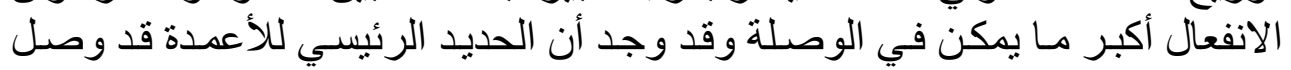

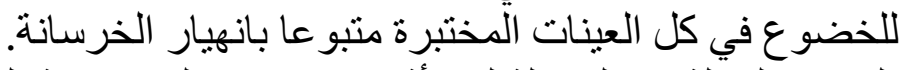

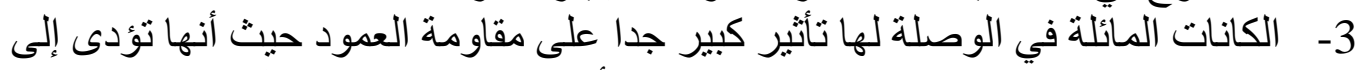

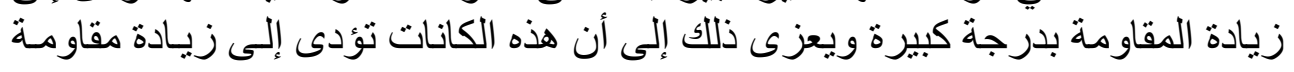

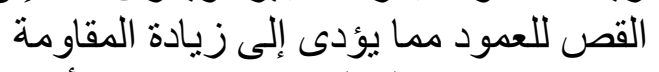

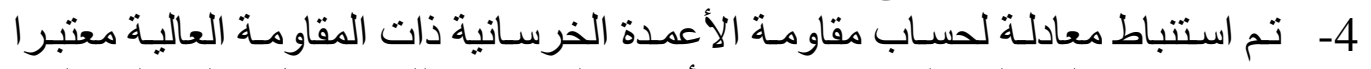

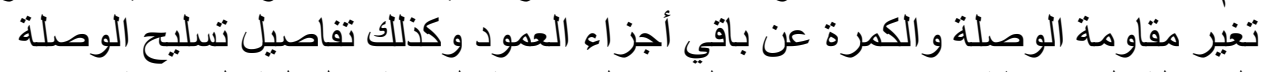

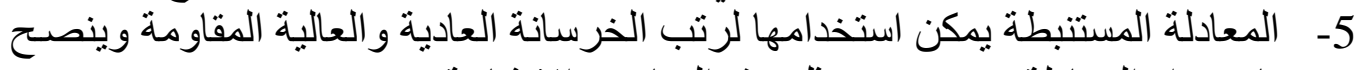
باستخدام المعادلة في تصميم مثل هذه العناصر الإنشائية. 